\title{
Comparison of Forage Intake and Digestibility by American Bison, Yak and Cattle
}

\author{
R. J. RICHMOND, R. J. HUDSON \& R. J. CHRISTOPHERSON
}

Richmond R. J., Hudson R. J. \& Christopherson R. J., 1977: Comparison of forage intake and digestibility by American bison, yak and cattle. Acta theriol., 22, 14: 225-230 [With 2 Tables].

Feed intake, selectivity and apparent digestibility coefficients of dry matter, protein and detergent fiber fractions were determined in groups of four yearling bison, yak and cattle. Diets of contrasting quality for these camparisons were provided by native sedge meadow hay, bromefescue grass hay and alfalfa hay. Feed intakes for bison and cattle were similar but considerably higher on a per unit body weight basis than for yak. Apparent digestibility coefficients for dry matter and detergent fiber fractions tended to be highest in bison followed by yak then cattle, a digestive superiority which was most marked on the grass hay diet. However, off-setting the digestive advantage of bison in relation to the other two species was an apparent higher digestible dry matter requirement for maintenance. Gains and feed conversion for cattle exceeded those of yak and bison on sedge and grass hays but not on alfalfa.

[Dept. Anim. Sci., Univ. Alberta, Edmonton, Canada T6G 2E3].

\section{INTRODUCTION}

Several studies have compared the digestive characteristics of European bison (Bison bonasus) and cattle ( $\mathrm{S} z$ a n i a w ski, 1959; G ę b czyńsk a et al., 1974: Kow a l c z y k et al., 1976). It is of interest to compare results of similar studies on the American bison (Bison bison).

In Northern Canada, such studies are of pragmatic as well as academic interest. Spiralling production costs have resulted in renewed interes: in meat production from pasture and range. Particularly in more marginal areas productivity of grazing systems based on conventional agricultural animals remains low and opportunities for range improvement are limited by prohibitive input costs. Under such circumstances it has been claimed that indigenous or exotic herbivores may make an important contribution to the harvesting of native vegetation.

This study represents an initial phase in a program to evaluate a number of native and exotic herbivores as a basis for meat production. 
from marginal lands. Preliminary to more detailed physiological and ecological investigations, the digestive capabilities of bison and yak were compared with those of cattle.

\section{MATERIALS AND METHOD}

Bison, yak and cattle used in this study were provided and raised by a rancher in Western Alberta. Four female yearlings comprised the cattle group whereas one male and three female yearlings made up each of the yak and bison groups. The average initial body weights of the calves were 136, 173 and $263 \mathrm{~kg}$ for the yak, bison and cattle respectively. Animals were penned indoors individually and offered test forages in three treatment periods of three weeks duration. The study was conducted from March 31 to June 2 during which time animals were exposed to temperatures ranging from -30 to $+21^{\circ} \mathrm{C}$.

Test forages were sedge meadow hay (Corex sp.), brome-fescue grass hay, and alfalfa hay (Table 1). Following a two-week adjustment period during which voluntary feed intake was measured and forage-on-offer and refusals were

Table 1

Characteristics of experimental forages offered to bison, yak and cattle.

\begin{tabular}{lccr}
\hline & Alfalfa & Grass hay & Seäge \\
\hline Dry matter $\%$ & 88.54 & 90.38 & 89.48 \\
Protein (nitrogen $\times 6.25)$ & 18.74 & 6.59 & 8.30 \\
Neutral detergent fiber $(\%)$ & 42.47 & 63.24 & 70.20 \\
Acid detergent fiber $(\%)$ & 30.53 & 40.32 & 39.15 \\
\hline
\end{tabular}

sampled, feed and fecal samples from a one week period for each animal were pooled for determination of apparent digestibility coefficients for dry matter, nitrogen, neutral detergent fiber, hemicellulose and acid detergent fiber. A forage selectivity coefficient was calculated by dividing the nitrogen content of the feed actually consumed with that on offer.

Forage and feces analyses included Kjehldahl nitrogen (AOAC), (1960) and neutral detergent and acid detergent fibers (Goering \& Van Soest, 1970). In order to avoid stress induced by harnessing or confining animals for total collection, digestibility was determined by use of $6 \mathrm{NHCl}$ insoluble ash as an indigestible internal marker ( $\mathrm{McC}$ a rth y et al., 1974).

\section{RESULTS}

The results of the trial are summarized in Table 2. Significant contrasts in voluntary feed intake, forage selectivity, digestion and performance as reflected in body weight change were noted in the three bovids.

Voluntary feed intakes for all species varied inversely with neutral detergent fiber (cell wall) content. Feed intakes per unit body mass 
were similar for bison and cattle but higher than those shown by yak. Voluntary intakes of alfalfa by all species were greater than intakes of grass or sedge hays.

All bovids showed some forage selectivity as shown by comparison of feed-on-offer and refusals. The greatest opportunity for selection apparently existed with alfalfa and least with sedge. Generally, cattle were most selective and bison most indiscriminate.

Table 2

Comparative digestive capacites of cattle, yak and bison offered forages of varying auality.

\begin{tabular}{|c|c|c|c|c|c|c|c|c|c|}
\hline \multirow[b]{2}{*}{ Species } & \multirow{2}{*}{ 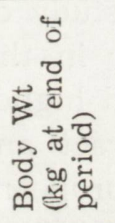 } & \multirow{2}{*}{ 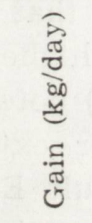 } & \multirow[b]{2}{*}{ 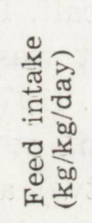 } & \multicolumn{5}{|c|}{ Apparent digestibility coefficients } & \multirow[b]{2}{*}{ 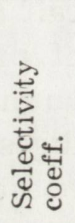 } \\
\hline & & & & 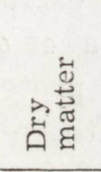 & 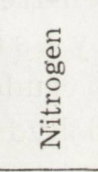 & $\begin{array}{l}\text { 留 } \\
\text { 学 }\end{array}$ & 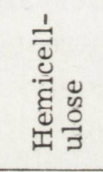 & 兵 & \\
\hline \multicolumn{10}{|c|}{ Sedge } \\
\hline Cattle & 281.4 & .42 & .013 & 76.00 & 83.00 & 67.50 & 75.75 & 64.25 & 1.76 \\
\hline Yak & 149.9 & -.05 & .008 & 63.00 & 54.00 & 69.75 & 79.75 & 61.75 & 0.96 \\
\hline Bison & 176.7 & -.48 & .009 & 64.25 & 54.25 & 69.00 & 76.50 & 62.75 & 1.04 \\
\hline \multicolumn{10}{|c|}{ Grass } \\
\hline Cattle & 272.3 & .45 & .011 & 61.75 & 58.25 & 56.75 & 68.00 & 50.50 & 1.15 \\
\hline Yak & 141.3 & .04 & .008 & 70.75 & 57.50 & 70.00 & 81.00 & 63.75 & 1.10 \\
\hline Bison & 169.7 & -.10 & .011 & 74.00 & 70.00 & 71.50 & 79.25 & 67.25 & 1.09 \\
\hline \multicolumn{10}{|c|}{ Alfalfa } \\
\hline Cattle & 281.4 & .00 & .009 & 57.50 & 46.50 & 63.25 & 73.50 & 55.00 & 0.80 \\
\hline Yak & 151.0 & .46 & .010 & 72.00 & 79.50 & 62.50 & 72.50 & 58.50 & 1.42 \\
\hline Bison & 186.8 & .81 & .013 & 77.50 & 83.75 & 68.25 & 76.50 & 65.00 & 1.08 \\
\hline \multicolumn{10}{|c|}{ Source of variation } \\
\hline Species & & ns & $* * *$ & $* * *$ & $* * *$ & $* * *$ & $* *$ & *** & * \\
\hline Forages & & $* * *$ & $* * *$ & $* * *$ & $* * *$ & ns & ns & ns & $* * *$ \\
\hline Interactions & & $* * *$ & ns & * & ** & ** & ** & ** & $* * *$ \\
\hline
\end{tabular}

$* P<.05$,

** $P<.01$,

*** $P<.001$

Apparent digestibility coefficients for nitrogen and for each of the forage detergent fractions tended to parallel changes in dry matter digestibility. Bison digested all forages most efficiently. Yak were more efficient than cattle on grass and sedge hays but not on alfalfa. In spite of this contrasting pattern of digestive efficiencies, cattle surprisingly tended to show superior rates of gain or lesser weight losses on sedge and grass hay although not on alfalfa. 


\section{DISCUSSION}

Both bison and yak are noted for their ability to survive in harsh environments. Their apparent superior ability to digest low quality forages often is cited as one reason for their success. This study confirmed their alleged digestive superiority. However, when performance was measured in terms of voluntary feed intake, gain or feed conversion efficiency under the conditions of the study, cattle were best able to utilize low quality forage whereas bison and yak fared somewhat better on higher quality forage.

Several studies have compared the digestive capacities of bison and cattle. Szania w k i (1959) compared a 6 month old European bison calf (Bison bonasus) with a domestic bull calf. In that study digestibility of protein, fiber and nitrogen-free extract was higher in the domestic animal. In contrast Gęb c z yńs ka et al. (1974) noted higher apparent digestibility coefficients for crude protein, ether extract and ash but not celluose or soluble carbohydrate in two adult European bison. In comparing their results with those of $\mathrm{Szaniaw} \mathrm{ski} \mathrm{(1959)} \mathrm{the} \mathrm{authors}$ pointed to the late weaning and hence poorer digestive tract development of free-ranging bison calves.

Although closely related to the American bison, the European bison differs markedly in feeding behaviour in that it selects a high proportion of browse (Borowski et al., 1967). More relevant comparative data for American bison and cattle were provided by Peden (1971) and $\mathrm{Peden}$ et al. (1974) who used the nylon-bag digestion technique with ruminally fistulated animals. These results showed a definite digestive superiority of bison on lower quality forages (winter grazing) which was lost on higher quality diets (spring grazing).

Although a standard of comparison for yak is not available, the results of the present study with respect to bison are supported by studies on the feedlot performances of bison, cattalo and hereford calves (P eters, 1958). The observed contrast was explained on the basis of the inferior voluntary intake of bison although a lower efficiency of utilization of ingested feed also was evident.

It is perhaps surprising that the high digestive efficiency of bison was not accompanied by higher rates of gain. One explanation for the pattern of results obtained could be the differential response of the three species to indoor confinement. Both bison and yak resisted handling and appeared more stressed than cattle. This could explain lower feed intake of yak and low metabolic efficiency of bison. However, if this were a significant factor then the apparent superiority of both species on alalfa demands explanation. 
Since weight changes within each trial period were small, it is possible that rumen fill or body water content could have contributed to the observed differences. If this were the case, weight change over the three trial periods would be more reliable criterion for evaluating the three species. However, even on this basis cattle maintained their productive superiority under the conditions of confinement imposed during the study.

Other explanations are speculative. Seasonal facturs may have contributed to the observed differences and it cannot be ruled out that studies repeated at other times of the year would yield different results. A number of wild ruminants adapt to seasonal environments with endogenous bioenergetic rhythms in which voluntary feed intake, digestive capacity and growth is restricted during the winter months ( $\mathrm{N}$ ordan et al., 1968; M c E w a n, 1970).

Finally, it is possible that low forage quality is not the major limiting factor in the environments in which bison and yak evolved. Other physiological, ecological and behavioral adaptations may account for their well-known ability to survive and reproduce in harsh environments.

\section{REFERENCES}

1. Association of Official Agricultural Chemists, 1960: Official Methods of Analysis of the Association of Official Agricultural Chemists. 9th Edition.

2. Borowski S., Krasiński Z. \& Miłkowski L., 1967: Food and role of European bison in forest ecosystems. Acta theriol., 12: 367-376.

3. Commonwealth Bureau of Animal Breeding and Genetics, undated: Yaks and Yak Hybrids. Annotated Bibliog, 182 (1937-1971). 7p.

4. G ębczyńska Z., Kowalczyk J., Krasińska M. \& Ziołecka A., 1974: A comparison of the digestibility of nutrients by European bison and cattle. Acta theriol., 19: 283-289.

5. Goering H. K. \& Van Soest P. J., 1970: Forage fiber analysis (apparatus, reagents, procedures and some applications). ARS U.S. Government Printing Office, Washington.

6. Kowalczyk J., G ębczyńska Z. \& Krasińska M., 1976: The digestibility of nutrients of natural diet by European bison in different seasons. Acta theriol., 21: 141-146.

7. McCarthy J. F., Aherne F. X. \& Okai D. B., 1974: Use of $\mathrm{HCl}$ insoluble ash as an index material for determining apparent digestibility with pigs. Can J. Anim. Sci., 54: 197-199.

8. M E Ewan E. H., 1970: Energy metabolism of barren ground caribou. Can. J. Zool., 48: 391-392.

9. Nor d a n H. C., C ow a n I. McT. \& W o o d A. J., 1968: Nutritional requirements and growth of black tailed deer in captivity. [In: "Comparative Nutrition of Wild Animals« ed. M. A. Crawford]. Symp. zool. Soc., Lond., 21: 89-96.

10. Peden D. G., 1971: A comparison on shortgrass prairie in winter. Presented to Am. Soc. Mammal. Annual Meet., Vancouver. 
11. Peden D. G., Van Dyne G. M., Rice R. W. \& Hansen R. M., 1974: The trophic ecology of Bison bison on shortgrass prairie. J. Appl. Ecol., 11: $489-498$.

12. Peters H. F., 1958: A feedlot study of bison, cattalo and hereford calves. Can. J. Anim. Sci., 38: 87-90.

13. Szaniawski A., 1958: Comparison of digestibility of feedingstuffs with different protein ratios for calves of domestic cattle and of bison, Bison bonasus. Acta theriol., 3: 318-319.

Accepted, July 29, 1976.

\section{R. J. RICHMOND, R. J. HUDSON i R. J. CHRISTOPHERSON}

\section{POROWNANIE ZAPOTRZEBOWANIA POKARMOWEGO I STRAWNOSCI \\ U BIZONA AMERYKAŃSKIEGO, JAKA I BYDEA}

\section{Streszczenie}

Oznaczono zapotrzebowanie pokarmowe, wybiórczość i współczynniki strawności suchej masy, białka oraz składników węglowodanowych u rocznych bizonów, jaków i bydła. Do doświadczeń wzięto po cztery zwierzęta każdego gatunku i karmiono je sianem turzycy, stokłosy kostrzewy lub lucerny, zróżnicowanym pod względem zawartości włókna (Tabela 1).

Zapotrzebowanie pokarmowe u bizona i bydła było podobne i wyraźnie wyższe na jednostkę ciężaru ciała niż u jaka. Współczynniki strawności suchej masy i włókna malały w kolejności: bizon, jak, bydło (Tabela 2), przy czym różnice te były najwyraźniej zaznaczone w przypadku siana. Zapotrzebowanie bytowe bizona było wyższe niż dwu pozostałych gatunków, choć zrównoważone przez wyższy współczynnik strawności. Wskaźnik przyrostu i przyswajania pokarmu u bydła był wyższy niż u jaka i bizona w przypadku suszonej turzycy i siana, natomiast w przypadku lucerny różnic nie było. 